\title{
Cover Crop Mulch and Fungicide Program Affect Development of Septoria Leaf Spot and Marketable Yield in Processing Tomato Production
}

\author{
Christian A. Wyenandt ${ }^{1,5,6}$, Landon H. Rhodes ${ }^{2}$, and Richard M. Riedel ${ }^{4}$ \\ Department of Plant Pathology, The Ohio State University, Columbus, \\ $\mathrm{OH} 43210$ \\ Mark A. Bennett ${ }^{3}$ \\ Department of Horticulture and Crop Science, The Ohio State University, \\ Columbus, OH 43210
}

Additional index words. hairy vetch, Vicia villosa, winter rye, Secale cereale, soilborne disease, Septoria lycopersici, Lycopersicon esculentum

\begin{abstract}
The development of septoria leaf spot in processing tomatoes grown on conventional (bare soil) beds or beds with chemically or mechanically killed winter rye (Secale cereale $\mathbf{L}$.) and hairy vetch (Vicia villosa Roth) cover crop mulch with or without fungicide was examined. The two fungicide treatment programs included fungicide applied weekly ( $7 \mathrm{~d})$ and a no fungicide control. In mulch bed systems without fungicide, septoria leaf spot caused $\approx \mathbf{5 0} \%$ defoliation 10 and $28 \mathrm{~d}$ later in 1997 and 1998 than in the conventional system, respectively. In both years, area under disease progress curve (AUDPC) values for septoria leaf spot development were lower with the presence of a chemically or mechanically killed mulch compared with the conventional bed system when no fungicide was applied. In 1997, there were no significant differences in AUDPC values for septoria leaf spot development when fungicide was applied weekly. In 1998 , AUDPC values were lower in both mulch systems compared with the conventional bed system when fungicide was applied weekly. At harvest in both years, defoliation was highest in the no fungicide control treatment. In 1997, marketable yield was significantly higher in both mulch systems compared with the conventional bed system. Conversely, in 1998, marketable yield was significantly higher in the conventional bed system than in either mulch bed system.
\end{abstract}

Septoria leaf spot (Septoria lycopersici Speg.) is an important soilborne fungal disease of fresh market and processing tomatoes in midwestern states (i.e., Ohio and Indiana) and other tomato-producing areas. Septoria leaf spot overwinters on infected tomato debris and other solanaceous weed hosts such as horsenettle between crops (Jones et al., 1991). Tomato plants become infected during the production season when infested soilcarrying inoculum (spores) is splashed onto lower leaves during rainfall and overhead irrigation. Periods of high relativity, high temperatures, and leaf wetness favor the development of septoria leaf spot during the

Received for publication 13 Dec. 2007. Accepted for publication $24 \mathrm{Jan} .2008$.

Funding for this research provided by National Research Initiative Competitive Grants Program (NRICGP 96-35313-3620).

${ }^{1}$ Former Graduate Research Assistant.

${ }^{2}$ Associate Professor.

${ }^{3}$ Professor.

${ }^{4}$ Professor Emeritus.

${ }^{5}$ Current address: Rutgers University, Extension Specialist, 121 Northville Road, Bridgeton, NJ 08302 .

${ }^{6}$ To whom reprint requests should be addressed; e-mailwyenandt@aesop.rutgers.edu production season (Jones et al., 1991) and if not managed properly, defoliation of tomato plants can be as high as $100 \%$. Because of the threat of diseases such as septoria leaf spot, fungicides are applied to nearly $100 \%$ of the processing tomato crops grown in the Midwest (Precheur et al., 1992). If necessary, tomato growers control septoria leaf spot with weekly protectant fungicide applications during the production season.

Cover crops left on the soil surface during the production season can act as a physical barrier that reduces soil splashing from rainfall and overhead irrigation. Artificial inoculation of tomato plants confirmed that soil splashing from precipitation is the primary means for spore dissemination and an important factor contributing to the development of septoria leaf spot epidemics in tomatoes (Parker et al., 1995). Rainfall and overhead irrigation act to initiate primary infections early in the growing season by splashing contaminated soil into the plant canopy. Soil particles can help spread fungal pathogens such as Septoria lycopersici, which overwinter in plant debris buried in the soil. Few studies have examined the effects of cover crop mulches on soilborne fungal disease in processing tomato production. Growing commercial processing tomato cultivars Ohio
7870 and Heinz 8704 in a zone-tilled mulch consisting of rye did not affect marketable yield or percent fruit with mold (early blight caused by Alternaria solani, anthracnose fruit rot caused by Colletotrichum coccodes, and soil rot caused by Rhizoctonia solani). The zone-tilled mulch system also had no effect on defoliation caused by early blight (Louws et al., 1996).

The objective of this study was to evaluate the effects of a chemically or mechanically killed winter rye and hairy vetch cover crop mulch on septoria leaf spot development in processing tomato production.

\section{Materials and Methods}

Location and design of field experiments. Field experiments were conducted in 1997 and 1998 at the Waterman Agricultural and Natural Resources Laboratory in Columbus, OH (Franklin County). In Sept. 1996, a randomized split-block design with three bed systems (bare soil, chemically, or mechanically killed mulch) as main plot and two fungicide treatments (none or weekly) as subplot with four replications were established on a Crosby silt loam soil ( $\mathrm{pH}$ of 6.7 and organic matter less than 1\%). In 1997, the main plot bed system for each bare soil, chemically, and mechanically killed mulch treatment contained eight 1.5 -m wide beds by $9.0 \mathrm{~m}$ long spaced on $1.5-\mathrm{m}$ centers. Each main plot was divided into two fungicide treatment subplots consisting of four $1.5-\mathrm{m}$ wide beds by four rows wide by $7.5 \mathrm{~m}$ long with the outer two rows of each subplot serving as guard rows. In Sept. 1997, a split-block design with the bed system as the main plot and fungicide treatment as the subplot with five replications was established on a different field at the same facility on a Kokomo silty clay loam soil ( $\mathrm{pH}$ of 6.7 and organic matter less than 1\%). Similarly, the main plot bed system for each bare soil, chemically, and mechanically killed mulch treatment contained eight $1.5-\mathrm{m}$ wide beds by $7.5 \mathrm{~m}$ long spaced on 1.5-m centers. Each main plot was divided into two fungicide treatment subplots consisting of four $1.5-\mathrm{m}$ beds by four rows wide by $6.0 \mathrm{~m}$ long with the outer two rows of each subplot serving as guard rows.

Field preparation. To ensure high inoculum levels of $S$. lycopersici, both fields used in the study had been in continuous tomato production for at least 3 years. Field preparation in the Fall 1996 and 1997 included disking, moldboard plowing, and new bed formation. Before disking fields in Fall 1996 and 1997 , fertilizer $(0 \mathrm{~N}-46 \mathrm{P}-0 \mathrm{~K}$ and $0 \mathrm{~N}-$ $0 \mathrm{P}-61 \mathrm{~K}$ at $55 \mathrm{~kg} \cdot \mathrm{ha}^{-1}$ each) was broadcast onto the soil surface.

Cover crop establishment and kill. On 12 Sept. 1996 and 27 Sept. 1997, a cover crop mix of winter rye (Secale cereale L.) and hairy vetch (Vicia villosa Roth.) seed was sown at $55 \mathrm{~kg} \cdot \mathrm{ha}^{-1}$ each on chemically and mechanically killed main plots. Water was applied with overhead irrigation on 14 Sept. 1996 and on 1 and 6 Oct. 1997 to promote 
seed germination and cover crop establishment. On 16 May 1997 and 29 Apr. and 23 May 1998, chemically killed bed systems were desiccated using 2,4-D at $2.3 \mathrm{~L} \cdot \mathrm{ha}^{-1}$ and glyphosate at $4.6 \mathrm{~L} \cdot \mathrm{ha}^{-1}$. For mechanically killed bed systems, a mechanical undercutter previously developed and described by Creamer et al. (1995) was used to cut the cover crop at $\approx 5-\mathrm{cm}$ soil depth and roll residue flat on the surface of raised beds leaving a mulch layer with minimal soil intrusion. On 21 May 1997, mechanically killed cover plots were mowed to a height of $60 \mathrm{~cm}$ before mechanical undercutting. On 23 May 1997 and 29 Apr. and 11 May 1998, mechanically killed cover crop plots were undercut with minimal soil disruption leaving intact cover crop mulch on the bed surface. On 23 May 1997 and 12 May 1998, all chemically killed cover crop plots were flat rolled with a 3-m wide cultipacker.

Tomato transplanting and fertilizer application. Five-week-old transplants of processing tomato cv. Peto 696 in 288-size plug trays were obtained in 1997 and 1998 from a local tomato processor. Transplants were allowed to harden 7 to $10 \mathrm{~d}$ outdoors before transplanting. On 27 to 28,30 to 31 May, 1 to 2 June 1997, and 26 to 28 May 1998, tomatoes were transplanted $30 \mathrm{~cm}$ apart in single rows into the raised beds using a RJV 600 Plug Planter Unit (RJ Equipment, Blenheim, Ontario, Canada) and by hand when necessary. Each transplant in 1997 received $200 \mathrm{~cm}^{3}$ liquid fertilizer $(10 \mathrm{~N}-$ $10 \mathrm{P}-10 \mathrm{~K}$ ) and in 1998, $200 \mathrm{~cm}^{3}$ liquid fertilizer $(10 \mathrm{~N}-52 \mathrm{P}-10 \mathrm{~K})$ at planting. On 12 June 1997 , urea $(46 \mathrm{~N}-0 \mathrm{P}-0 \mathrm{~K})$ and on 7 and 20 July 1998, sulfur-coated urea $(34 \mathrm{~N}-$ $0 \mathrm{P}-0 \mathrm{~K}$ ) was broadcast at $55 \mathrm{~kg}$ actual nitrogen per hectare on the entire field.

Fungicide treatments. Beginning on 20 June in both years, chlorothalonil (Bravo Ultrex WDG, a.i. at $3.1 \mathrm{~kg} \cdot \mathrm{ha}^{-1}$; Syngenta Crop Protection, Greensboro, NC) was applied to the weekly fungicide program subplots to control early blight. Benomyl (Benlate 50WP, a.i. at $1.1 \mathrm{~kg} \cdot \mathrm{ha}^{-1}$; DuPont Agricultural Products, Wilmington, DE) was tank-mixed with each weekly chlorothalonil fungicide application beginning on 3 Aug. 1997 and 2 July 1998 for control of septoria leaf spot until the end of the production season. Fungicides were applied at $414 \mathrm{kPa}$ and at $470 \mathrm{~L} \cdot \mathrm{ha}^{-1}$ using a tractor-mounted $\mathrm{CO}_{2}$ pressurized boom sprayer with five conejet visiflo hollow cone spray tip (TXVS-12) nozzles (TeeJet Technologies, Wheaton and Springfield, IL). Spray boom height was maintained $30 \mathrm{~cm}$ above the tomato canopy. In 1997 and 1998, total number of fungicide applications for no fungicide and weekly fungicide application programs were zero and 11 , respectively.

Assessment of foliar disease caused by septoria leaf spot. In 1997 and 1998, weekly visual disease ratings were performed in all treatments to determine the severity of septoria leaf spot. A $1.5-\mathrm{m}$ section in the center of each subplot treatment row was visually rated using a scale of 0.0 to 1.0 (0.05 increments) based on the percent defoliation $(0.0=$ no disease and $1.0=100 \%$ defoliation) caused by septoria leaf spot. In both years, care was taken to distinguish between defoliation caused by septoria leaf spot and that caused by other pathogens such as bacterial canker, Clavibacter michiganense subsp. michiganense (Smith), or weather damage such as hail or wind. In both years, the weekly severity ratings were used to develop disease progress curves and arsine transformed area under disease progress curve (AUDPC) values were calculated for all subplot treatments.

Tomato harvest and assessment of marketable yield. Harvest dates were 30 Aug. and 11 Sept. 1997 and 31 Aug. and 10 Sept. 1998 for no spray and weekly fungicide programs, respectively. All fruit from two $1.5-\mathrm{m}$ long row sections from the center of each subplot were harvested to determine marketable yield (weight in kilograms per plot), which included all marketable (i.e., not diseased) red, green, and pink fruit.

Statistical analysis. Analysis of variance using SAS (version 7.0; SAS Institute, Cary, NC) was performed to determine the effects of cover crop mulch (main plot) and fun- gicide treatment (subplot) on the development of septoria leaf spot and marketable yield. Before analysis, AUDPC values were transformed using the arsine square root method. Treatment means for AUPDC value and marketable yield were compared using Fisher's protected least significant difference test.

\section{Results and Discussion}

Cover crop establishment and kill. In both years, a winter rye/hairy vetch cover crop mulch was successfully established in the fall and killed by herbicide application or undercutting the following spring before processing tomato transplanting. A rainfall event on 29 Apr. 1998 (on the day of herbicide application and undercutting) resulted in incomplete dessication in the chemically killed and regrowth in the mechanicallykilled cover crop bed systems and a second herbicide application and undercutting was done. In both years, chemical kill immediately followed by rolling and mechanical undercutting of the winter rye and hairy vetch cover crop resulted in uniform mulch distribution over bed surfaces. Visually rating percent groundcover of chemically and mechanically killed cover crop mulch plots immediately after chemical or mechanical dessication before tomato transplanting was greater than $90 \%$ in each year. At harvest in 1997 and 1998, soil coverage by mulch litter visually estimated from chemically and mechanically killed cover crop plots was $63 \%$ to $66 \%$ at harvest, respectively (data not shown).

Cover crop effects on marketable yield. There was no significant interaction between bed system and fungicide treatment; therefore, marketable yields were combined across fungicide treatment subplots in each year (Table 1). In 1997, marketable yields in both mulch systems were significantly higher compared with the conventional (bare soil) bed system (Table 1). Conversely, in 1998, marketable yields were lower in both mulch systems than in the conventional system

Table 1. Marketable yield and AUDPC values for no weekly fungicide and weekly fungicide treatments on three different bed systems in 1997 and 1998 at the Ohio State University Waterman Agricultural and Natural Resources Laboratory, Columbus, $\mathrm{OH}$.

\begin{tabular}{|c|c|c|c|c|c|c|}
\hline \multirow{2}{*}{$\overline{\text { Bed system }}{ }^{y}$} & & & \multicolumn{4}{|c|}{ AUDPC value ${ }^{z}$} \\
\hline & \multicolumn{2}{|c|}{ Marketable yield ${ }^{\mathrm{x}}$} & \multicolumn{2}{|c|}{ No weekly fungicide ${ }^{w}$} & \multicolumn{2}{|c|}{ Weekly fungicide ${ }^{\mathrm{w}}$} \\
\hline Conventional & $13.2 \mathrm{~b}$ & $25.7 \mathrm{a}$ & $2074 \mathrm{a}$ & $2542 \mathrm{a}$ & 705 & $500 \mathrm{a}$ \\
\hline Mechanical kill & $25.6 \mathrm{a}$ & $14.3 \mathrm{~b}$ & $1401 \mathrm{~b}$ & $955 \mathrm{~b}$ & 632 & $275 \mathrm{ab}$ \\
\hline \multirow[t]{2}{*}{ LSD } & 7.5 & 5.6 & 389 & 521 & NS & 244 \\
\hline & & \multicolumn{2}{|c|}{1997} & & \multicolumn{2}{|c|}{1998} \\
\hline ANOVA & & Marketable yield & AUDPC & & Marketable yield & AUDPC \\
\hline $\mathrm{BS} \times \mathrm{F}$ & & 0.6201 & $<0.0001$ & & 0.524 & $<0.0001$ \\
\hline
\end{tabular}

${ }^{\mathrm{z}}$ Arsine-transformed area under disease progress curves (AUDPC) for no fungicide and weekly fungicide treatment plots.

${ }^{\mathrm{y}}$ Bed system: conventional (bare soil), chemical kill (chemically killed cover crop mulch), and mechanical kill (mechanically killed cover crop mulch).

${ }^{\mathrm{x}}$ Marketable yield is sum of all harvested red, green, and pink fruit per two 1.5-m long treatment plots for a single season-end harvest.

${ }^{\text {wF }}$ ungicide treatment in which no fungicide equals no fungicide applied season-long and weekly fungicide equal 11 fungicide applications applied season-long. Values within a column followed by different letters are statistically significant at $P \leq 0.05$ according to Fisher's protected least significant difference (LSD).

ANOVA $=$ analysis of variance; $\mathrm{Ns}=$ nonsignificant. 
(Table 1). Yield may or may not increase when organic mulches are incorporated into low-input fresh market and processing tomato production systems (Abdul-Baki and Teasdale, 1993; Creamer et al., 1996; Louws et al., 1996; Price and Baughan, 1987). In a study comparing four processing tomato production systems differing in cover crop and chemical inputs, the conventional system (bare soil) produced a significantly greater yield of red fruit than integrated (cover crop mix with reduced chemical input) or organic systems (cover crop mix with no synthetic chemical input) (Creamer et al., 1996). At another location in the same Ohio study, there were no significant differences in red fruit yield among production systems (Creamer et al., 1996). In the present study, reduced yields in both mulch systems in 1998 were most likely the result of limited rainfall and soil moisture exacerbated by the presence of the cover crop mulch on the soil surface during the production season.

Effects of septoria leaf spot development on marketable yield. In 1997 and 1998, the earliest symptoms of septoria leaf spot were detected $\approx 1$ Aug. and 6 July, respectively, with the initial onset of epidemics starting $\approx 7$ $\mathrm{d}$ later in each year (Fig. 1). The septoria leaf spot epidemics that occurred in central Ohio in 1997 and 1998 may have occurred too late in the growing season to have a detrimental effect on marketable yield. In each year, defoliation caused by septoria leaf spot was decreased when a calendar-based (weekly) fungicide program was used to control the pathogen (Table 1). Yield loss resulting from septoria leaf spot has been described as a lateseason phenomenon, and the disease did not significantly reduce yields when leaf damage (defoliation) was less than $50 \%$ by midAugust (Elmer and Ferrandino, 1995). In Ohio, mid-August is approximately threefourths into the processing tomato production season.

Fungicide effect on foliar disease caused by septoria leaf spot. In both years, percent defoliation caused by septoria leaf spot was highest in each bed system when no fungicide was applied season-long. When no fungicide was applied season-long, percent defoliation was greater than $90 \%$ by harvest in 1997 and greater than $50 \%$ by harvest in 1998 (Fig. 1). Area under disease progress curves were calculated for each fungicide treatment in 1997 and 1998 with significant interaction detected between main plot (cover crop) and subplot (fungicide treatments) effects (Table 1). In both years, AUDPC values for both no fungicide/mulch systems were significantly lower than the no fungicide/conventional bed system, suggesting that presence of the cover crop alone reduced or delayed septoria leaf spot development (Table 1). In 1997, there were no differences in AUDPC values between bed systems with weekly fungicide applications (Table 1). However, when fungicide was applied weekly in 1998, final AUPDC values were significantly lower in both mulch systems than in the conventional bed system, respectively (Table 1).
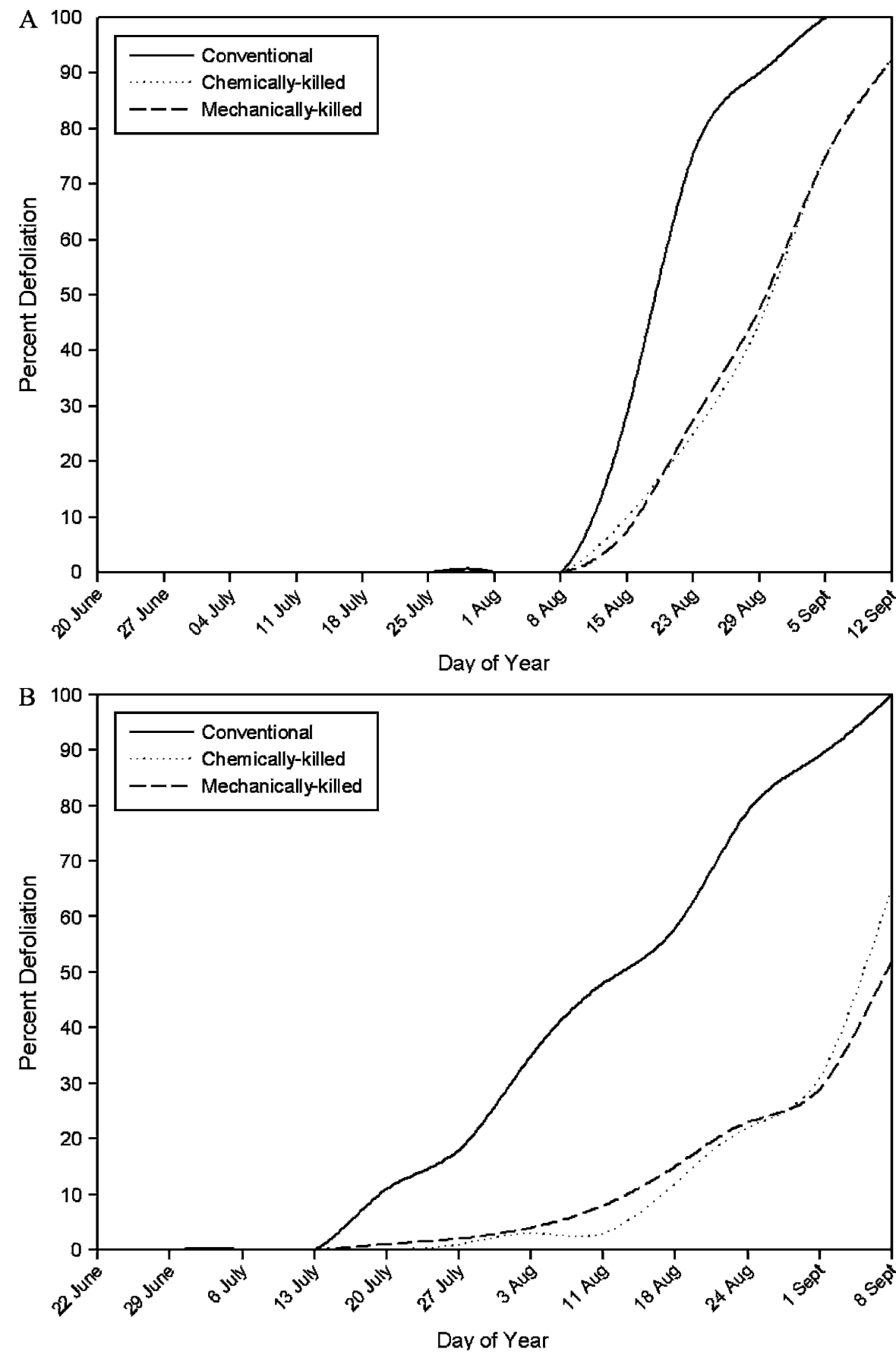

Fig. 1. Disease progress curves for septoria leaf spot (Septoria lycopersici) in conventional (bare soil) bed, chemically killed mulch, and mechanically killed mulch beds with no fungicide treatment in 1997 (A) and 1998 (B) at the Ohio State University Waterman Agricultural and Natural Resources Laboratory, Columbus, $\mathrm{OH}$.

Cover crop effect on septoria leaf spot development. Total rainfall and leaf wetness hours were $31.2 \mathrm{~cm}$ and $686 \mathrm{~h}$ for 20 June to 12 Sept. 1997 and $15.9 \mathrm{~cm}$ and $611 \mathrm{~h}$ for 22 June to 13 Sept. 1998. Initial defoliation caused by septoria leaf spot in 1997 was not visually detected until $\approx 8$ Aug. in the no fungicide/cover crop mulch systems (Fig. 1). On 15 Aug., defoliation by septoria leaf spot was estimated at $10 \%$ in no fungicide/cover crop mulch systems and $30 \%$ in the no fungicide/conventional bed (Fig. 1). By 29 Aug., defoliation caused by septoria leaf spot in the conventional bed system was greater than $90 \%$ compared with only $40 \%$ in no fungicide/cover crop mulch systems (Fig. 1). Parker et al. (1995) determined that the rapid development of septoria leaf spot was accompanied by abundant and frequent rainfall and that during wet years, there may be an explosive potential of septoria leaf spot. Defoliation did not reach $90 \%$ in the no fungicide/ cover crop mulch systems until 12 Sept. (Fig. 1). In general, defoliation caused by septoria leaf spot was delayed $\approx 10$ to $14 \mathrm{~d}$ in the presence of a cover crop mulch when compared 
with the same percentage of defoliation in the conventional bed system at the different times during the 1997 production season.

Septoria lycopersici conidia are thought to infect older leaves lower in the plant canopy at the onset of an epidemic. The logarithm of the disease severity (lesions per square centimeter of leaf) was linearly correlated with the logarithm of inoculum density (spores per square centimeter of leaf), and older leaves were more susceptible than younger leaves to septoria leaf spot when inoculum densities were high $\left(10^{4}\right.$ spores per square centimeter of leaf) (Elmer and Ferrandino, 1995). However, no quantitative information was obtained on how leaves of different ages were affected by septoria leaf spot. In the present study, the presence of a killed cover crop mulch may have helped reduce initial inoculum densities from reaching the older leaves closest to the soil surface thus reducing or delaying the development of the septoria leaf spot epidemic in 1997.

In 1998, earliest symptoms of septoria leaf spot were visually detected in all bed systems much earlier in the production season ( $\approx 6$ July) than in $1997(\approx 1$ Aug.) (Fig. 1). Elmer and Ferrandino (1995) suggested that a low incidence of septoria leaf spot may develop under unfavorable conditions and that leaf abrasions may allow spores to infect in the absence of dew. In 1998, defoliation caused by septoria leaf spot approached $50 \%$ on 11 Aug. in the no fungicide/conventional bed and on 8 Sept. in the no fungicide/cover crop mulch systems almost 4 weeks later (Fig. 1). However, by mid-August in 1998, the projected cutoff date for yield loss resulting from septoria leaf spot was estimated at $70 \%$ in the no fungicide/conventional bed and $20 \%$ in no fungicide/cover crop mulch systems (Fig. 1). The earlier detection of septoria leaf spot in 1998 may be similar to the findings of Ferrandino and Elmer (1992) that septoria leaf spot may develop under unfavorable conditions. The slower development of septoria leaf spot in both killed cover crop mulch systems in 1998 may have also been the result of a lower amount of initial inoculum reaching the plant canopy. The further delay in the epidemic may have been the result of unfavorable conditions (e.g., less rainfall, less leaf wetness) for disease development during the later stages of the growing season in 1998 .

\section{Conclusion}

In this study, the use of a fall-sown winter rye and hairy vetch cover crop mulch in processing tomato production was evaluated for its influence on the development of septoria leaf spot. The cover crop mulch was either chemically or mechanically killed and left on the soil surface before tomato transplanting to act as a physical barrier to prevent spore dispersal of the soilborne fungal disease, S. lycopersici, through soil splashing. The prevention of soil splashing may be critical for reducing the amount of potential inoculum from reaching the tomato plant canopy and inciting a disease such as septoria leaf spot. In both years of this study, septoria leaf spot was detected on tomato foliage at the same time in bare soil and killed cover crop mulch systems, yet there was a delay in the development of septoria leaf spot in processing tomatoes grown on a fall-sown winter rye and hairy vetch cover crop mulch. Using cover crop mulches such as winter rye or hairy vetch may help reduce initial inoculum levels of soilborne fungal foliar pathogens such as septoria leaf spot from reaching the plant canopy by preventing inoculum dispersal through soil splashing during precipitation events. Surface topography of groundcover and plant canopy were major factors controlling splash dispersal of C. acutatum (anthracnose of strawberry) through effects on splash droplet trajectories and loss of inoculum (Yang et al., 1990). Straw mulch alone provided $95 \%$ to $99 \%$ control of Phytophthora cactorum, and straw mulch between the rows was equally or more effective than fungicides for controlling leather rot of strawberry (Ellis et al., 1998).

Cover crop mulches desiccated and left intact on the surface to act as a physical barrier may be more important in reducing soilborne fungal diseases that attack fruit such as Phytophthora spp. (Buckeye rot) of tomato or Fusarium fruit rot (Fusarium spp) of pumpkin (Cucurbita pepo), which infect fruit that lay in direct contact with the soil during the production season.

\section{Literature Cited}

Abdul-Baki, A.A. and J.R. Teasdale. 1993. A notillage tomato production system using hairy vetch and subterranean clover mulches. HortScience 28:106-108.

Creamer, N.G., M.A. Bennett, B.R. Stinner, and J. Cardina. 1996. A comparison of four processing tomato production systems differing in cover crop and chemical inputs. J. Amer. Soc. Hort. Sci. 121:559-568.

Creamer, N.G., B. Plassman, M.A. Bennett, R.K. Wood, B.R. Stinner, and J. Cardina. 1995. A method for mechanically killing cover crops to optimize weed suppression. Amer. J. Altern. Agr. 10:157-162.

Ellis, M.A., W.F. Wilcox, and L.V. Madden. 1998. Efficacy of metalaxyl, fosetyl-aluminum, and straw mulch for control of leather rot caused by Phythophthora cactorum. Plant Dis. 82:329332.

Elmer, W.H. and F.J. Ferrandino. 1995. Influence of spore density, leaf age, temperature, and dew periods on septoria leaf spot of tomato. Plant Dis. 79:287-290.

Ferrandino, F.J. and W.H. Elmer. 1992. Reduction in tomato yield due to septoria leaf spot. Plant Dis. 76:208-211.

Jones, J.B., J.P. Jones, R.E. Stall, and T.A. Zitter (eds.). 1991. Compendium of tomato diseases. The American Phytopathological Society. APS Press, St. Paul, MN.

Louws, F.J., M.K. Hausbeck, J.F. Kelly, and C.T. Stephens. 1996. Impact of reduced fungicide and tillage on foliar blight, fruit rot, and yield of processing tomatoes. Plant Dis. 80:1251-1256.

Parker, S.K., M.L. Gleason, and F.W. Nutter, Jr. 1995. Influence of rain events on spatial distribution of septoria leaf spot of tomato. Plant Dis. 79:148-152.

Precheur, R.J., M.A. Bennett, R.M. Riedel, K.L. Wiese, and J. Dudek. 1992. Management of fungicide residues on processing tomatoes. Plant Dis. 76:700-702.

Price, H.C. and R.A. Baughan. 1987. Establishment of fresh market tomatoes in a no-till system. Acta Hort. 198:216-268.

Yang, X., L.V. Madden, L.L. Wilson, and M.A. Ellis. 1990. Effects of surface topography and rain intensity on splash dispersal of Colletotrichum acutatum. Phytopathology 80:11151120 . 